\title{
A rákbetegség rejtett rizikófaktorai: a szegénység, a tudatlanság és a felelőtlenség
}

\author{
Hidden risk-factors of cancer: poverty, ignorance and irresponsibility
}

Ismertető: $\quad$ Simon Tamás professor emeritus $\square$

Semmelweis Egyetem ÁOK, Népegészségtani Intézet

Beküldve: 2017. 11. 16.

doi: $10.24365 /$ ef.v58i4.210

Összefoglaló: A daganatos betegségek kialakulásának biológiai-élettani kockázati tényezői mellett nem elhanyagolhatók az egészség-magatartást meghatározó társadalmi-gazdasági, valamint tudati-ismereti tényezők sem. A cikk ez utóbbiakra fókuszál, általános és konkrét példákat vet fel és javaslatokat tesz befolyásolásuk érdekében.

Kulcsszavak: szegénység, tudatlanság, felelőtlenség, rizikótényezők, rákmegelőzés

Summary: Besides the biological-physiological risk factors of the development of tumorous diseases, the socio-economic factors and knowledge, which determine health behaviour should also be taken account. This article focuses on the latter, provides general and specific examples and makes suggestions about the way of influencing them.

Keywords: poverty, ignorance, irresponsibility, risk factors, cancer prevention

\section{BEVEZETÉS}

A 21. században a rákbetegség már nem egyenlő a halálos ítélettel, mert a tudomány állása szerint három statisztikailag feltételezett rákbeteg közül az egyiknél a fellépést meg lehet előzni, a másikat meg tudjuk gyógyítani, és csak a harmadikat fogjuk elveszíteni (matematikai valószínűség szerint); de időben történő, célzott beavatkozásokkal ő is tovább marad köztünk, viszonylag jó életminőségben. A fentiek csak a lehetőséget jelentik, tehát elvileg ezt tudja nyújtani a korszerú orvostudomány.

A lehetőségek az egészségügyi ellátórendszer keretén belül valósulhatnak meg, azonban sajnos az egészségügy (az ország fejlettségétól, társadalmigazdasági viszonyaitól függően) nem mindig tudja nyújtani azt, amit a tudomány már elérhetővé tenne. Hogy a lehetőségek minél nagyobb százalékban érvényesüljenek, át kell értékelnünk jelenlegi tudásunkat és gyakorlatunkat a mai Magyarországon is. Ha meg akarjuk előzni a rákot, akkor az is mert rizikófaktorokat kell figyelembe vennünk, értékelnünk:

- dohányzás,

- egészségtelen táplálkozás,

- a stresszfaktorok és a stressztúrés szintje,

- alkoholfogyasztás,

- környezetszennyezés.

Ha időben fel akarjuk fedezni a rákot, akkor szorgalmaznunk kell, hogy az egyén a gyanújeleket komolyan vegye, időben forduljon orvoshoz és vegyen részt a szűrővizsgálatokon. A már felfedezett rákbeteget pedig mindig abba a centrumba kell küldeni, ahol adottak a korszerű feltételek - patológiai diagnosztika, képalkotó diagnosztika, sebészi szakorvosi lehetőség, a sugárterápia lehetősége, a kemoterápia alkalmazásának lehetősége -, és van kellő gyógyítási tapasztalat is. 
$\mathrm{Az}$ egészséget több tényező határozza meg: életmód (35\%), környezet (30\%), öröklés (20\%), egészségügyi ellátás (15\%). Ha elemezzük ezt a négy, alapvetően meghatározó, befolyásoló, általános kockázati tényezőt, akkor kiemelten kell foglalkoznunk további három, a címben is kiemelt társadalmi meghatározottságú faktorral: a szegénységgel, a tudatlansággal és a felelőtlenséggel.

\section{KOCKÁZATOK AZ EGYÉN OLDALÁRÓL}

Felvetődik a kérdés, hogy mennyiben befolyásolják a fenti tényezők az esetleges öröklés meghatározó hatását. Az öröklött hatásokról mindenképpen jó, ha tudunk, komolyan vesszük azokat. (Az orvosnál, védőnőnél felvett anamnesztikus adatok között ezért is szerepelnek a családi előfordulásra vonatkozó kérdések.) Ha az egyén nem tudja, hogy ezek a hatások léteznek, akkor az, aki örökletesen is veszélyeztetett, valószínúleg nem tesz semmit az időbeni felismerésért, a kockázati helyzet megszüntetéséért (ez a tudatlanság esete).

A tudatlanság az egészségügyi ellátás eredményességét súlyosan hátráltatja azáltal, hogy a lakosság nem törekszik a megelőzésre, gyakran nem tudja, hogyan és hol lehet igénybe venni az egészségügyi ellátást. A beteg aktív közremúködése nélkül egészségi állapota nehezebben javul, illetve azt a hatékonyságot, amelyre ma már képes lenne az adott egészségügyi ellátás, így nem érheti el.

Napjaink gyakran felvetődő kérdése még a védőoltások dilemmája. Számos, védőoltással megelőzhető betegségre nagy fertőzési kockázatunk van. Ez a kockázat a védőoltásokkal megszüntethető. $\mathrm{Ha}$ nem veszünk részt a védőoltási programban, az részben a tudatlanság, részben a felelőtlenség körébe tartozik, ezeknek a mulasztásoknak súlyosan káros hatásaik lehetnek.'

Az életmód közismerten lehet veszélyeztető (megbetegítő), illetve védő (protektív) hatású. A védő tényezők tudatos alkalmazását főleg a tudatlanság és a felelőtlenség akadályozza.

Az egészséges életmód 12 pontjából általában csak négyet-ötöt ismernek az emberek. A többi hét szabály ismertségi szintje nem éri el az 50\%-ot, de van, amelyik a $10 \%$-ot sem.

Ezek a protektív tényezők a következők, védőhatásukat százalékban is kifejezve:

- egészséges táplálkozás 95\%,

- testmozgás 85\%,

- stressztürés 65\%,

- nemdohányzás 65\%,

- mérsékelt alkoholfogyasztás 57\%,

- drogtagadás $40 \%$,

- balesetvédelem 3\%,

- kiegyensúlyozott szexualitás 30\%,

- a környezetünk védelme, tisztelete $6 \%$,

- időben való orvoshoz fordulás $27 \%$,

- együttmúködés az egészségüggyel 3\%,

- személyi higiénia $12 \%$.

Amit az emberek nem élnek meg tudatosan, vagyis nincs tudomásuk róla, az tudatlanság. Ebből következik, hogy ha a valakinek nincsenek kellő ismeretei, nem tudja, miért és hogyan védekezzen.

Vannak szabályok, amelyeket az emberek általában eléggé ismernek ( $p l$. a rendszeres és szappanos kézmosás), de nem követik őket. Ez viszont az ismeretek birtokában felelőtlenség.

A környezet bizonyos esetekben egyre inkább az ember ellen fordul (szennyezett levegő, vizek, klímaváltozást fokozó ipari, közlekedési tevékenységek, a természeti kincsek pazarlása stb.). Miért fokozódnak a károsító hatások? Mert a fogyasztói társadalom fokozott igénybevételével folyamatosan károsítjuk, romboljuk a természeti környezetet. A 20. század második felétől a Homo sapiens, a gondolkodó ember kihalóban van. Ezt az emberiséget egy új, ön- és közveszélyes ember kezdi uralni, a "Homo naturum destruens", a természet- és környezetkárosító ember típusa. Ezt az embert a tudatlanság és a felelőtlenség vezérli. A két ártalmas jelenség elhatalmasodásáért a társadalom és az egyén együttesen felelős.

A környezet tudatos védelmét a gazdasági és egyéni szegénység egyaránt akadályozhatja, mivel pl. drágulnak az ipari és lakossági védelmi beruházások. Ezek elmaradását nem szabad engedni, és ez már össztársadalmi felelősség.

\footnotetext{
'A kötelező gyermekkori védőoltásokat Magyarországon az egészségbiztosítás ingyenesen nyújtja, elmulasztásuk a gyermekek egészséghez való alapvető jogát sérti, a gyermek szülője jogszabály szerint felelősségre vonható.
} 


\section{KOCKÁZATOK AZ ELLÁTÓI OLDALON}

Az egészségügyi ellátás egészséget meghatározó, pozitív hatásait az ország társadalmi-gazdasági helyzete, szegénysége gátolhatja, mivel az egészségügyi kiadásokra rendelkezésre álló kevés pénzből nem lehet minden jogos és indokolt ellátási szükségletet kielégíteni. Ez akadályozhatja a hatékony prevenciót, az időbeni felismerést és a gyógyítást egyaránt. Ha egy országban nincs megfelelő anyagi lehetőség arra, hogy a lakossághoz közel vigyük a genetikai tanácsadást, a magzati szűrővizsgálatokat (labor, ultrahang stb.), az egyes védőoltásokat, akkor a szegénység miatt nem lesznek elérhetők. Számos közepes és gyenge gazdaságú országban, főként Európán kívül, ez a helyzet.

Probléma lehet, ha az ellátók első vonala (az alapellátásban dolgozó háziorvos, házi gyermekorvos, védőnő) nem tudja, hogy vannak ilyen lehetőségek, illetve ha nem úgy és nem abban az időben javasolja a vizsgálatot, utalja be a gondozottat, ahogy azt a szakmai szabályok indokolják, az már szakmai felelőtlenség, sőt mulasztás.

Az egészségügyi ellátás egészséget befolyásoló kockázati tényezői lehetnek a felelőtlenség különböző formái:

- az általános döntéshozói pozitív hozzáállás hiánya,

- intézeten és hálózaton belül a szakmai szabályok negligálása,

- a lakossági compliance hiánya.
E három említett rizikófaktor meghatározza a többi érvényesülését is, ezért ellenük szigorúan fel kell lépni: az egyéneknek, az egészségügynek és a társadalomnak (és ezen belül döntéshozói és közigazgatási szinten egyaránt).

Legkevésbé a szegénységen tudunk egyénileg változtatni, ahhoz társadalmi-gazdasági beavatkozások kellenek, azonban a tudatlanság csökkentése és a felelőtlenség visszaszorítása mindannyiunk feladata, következetesen gondolni kell rá és tenni kell ellene.

\section{ÖSSZEGZÉS}

A címben felsorolt három, régi és mai kockázat eddig jobbára háttérben maradt az elemzések során. Számos pozitív irányba befolyásoló aktivitásra van ma már lehetőség ezeknek a tényezőknek a negatív hatásai ellen:

- Szisztematikusan kell gondolkodni megelőzésükről és megszüntetésükről.

- Következetesnek kell lenni és összehangolt beavatkozást kell végrehajtani egyéni és társadalmi szinten.

Tudomásul kell venni, hogy ezek negatív hatásai ellen az egyéneknek, a közösségeknek, az ellátórendszernek és ellátóhelyeknek, valamint a döntéshozóknak is lehet és kell is tenniük. 